\title{
TAKING SLIPPAGE SERIOUSLY: NONCOMPLIANCE AND CREATIVE COMPLIANCE IN ENVIRONMENTAL LAW
}

\author{
Daniel A. Farber ${ }^{*}$
}

"There is many a slip 'twixt the cup and the lip." Nowhere is this more true than in environmental law. In all areas of law, there are gaps between the "law on the books" and the "law in action," but in environmental law the gap is sometimes a chasm. ${ }^{2}$ At some level, this fact is well-known to everyone in the field. But, as scholars and teachers of environmental law, our focus has generally been elsewhere: on the standard-setting "cup" rather than the noncompliance "slip."

The core focus of environmental scholarship has been on the federal standards governing pollution, hazardous waste, and preservation of wilderness and wildlife. ${ }^{3}$ Much scholarship has addressed questions like the following:

- Should we base standards on feasibility and available technology, or on quantitative risk assessment and cost-benefit analysis ${ }^{4}$

- How much discretion should agencies have in setting standards? ${ }^{5}$

* Henry J. Fletcher Professor of Law and Associate Dean for Faculty Research and Development, University of Minnesota. Helpful comments were provided by Jim Chen, Dan Gifford, and the participants at the Georgetown Law and Economics Workshop and the Harvard Environmental Law Review Symposium on "Environmental Law: Trends in Legal Education \& Scholarship." 1906).

1. Palladus, $b k$. X, epigram 32, in The Greek ANthology (John W. Mackail ed.,

2. Consider, for instance, the following appraisal of the Toxic Substances Control Act ("TSCA"): "In working circles, TSCA is sometimes called 'the PCB Act,' which gives a fair idea of how one and a half pages [of the statute] that are strictly business can come to dominate sixty-four pages that are mostly talk." WiLliam H. RoDGERS, ENVIRONMENTAL LAW 492 (2d ed. 1994).

3. With numerous variations and some exceptions, the statutes require agencies such as the Environmental Protection Agency ("EPA") to take all feasible measures to attain some environmental goal, often in the form of a requirement of best available technology. For the author's views about this system's virtues and shortcomings, see generally DANIEL Farber, Eco-Pragmatism: Making Sensible Environmental Decisions IN aN UNCERTAIN WORLD (1999).

4. See Carnegie Commission on Science, Technology, and Government, Risk AND THE ENVIroNment: IMPROVING REgulatory DeCISION MAKING (1988); see also STEPHEN BREYeR, BREaKING THE Vicious CIRCLE: TOWARD EFFective RISK Regulation (1993); Lisa Heinzerling, Reductionist Regulatory Reform, 8 FordHAM EnvTL. L.J. 459 (1997); Robert Kuehn, The Environmental Justice Implications of Quantitative Risk Assessment, 1996 U. ILL. L. REv. 103; Thomas O. McGarity, A Cost-Benefit State, 50 ADMIN. L. Rev. 1 (1998); Cass R. Sunstein, Legislative Foreword: Congress, Constitutional Moments, and the Cost-Benefit State, 48 STAN. L. Rev. 247 (1996); Jonathan Baert Weiner, Risk in the Republic, 8 DUKE ENvTL. L. \& POL'Y F. 1 (1997).

5. See Thomas O. McGarity, The Expanded Debat" Over the Future of the Regulatory State, 63 U. CHI. L. REV. 1463 (1996); W. Kip Viscusi, Regulating the Regulators, 63 
- How rigorously should courts review the standards selected by the agency $?^{6}$

- Should we abandon or modify this system by using economic incentives instead of direct regulation of sources?

- How much authority should local governments have to set their own standards?

Each of these questions has given rise to a rich debate, including many suggestions to shift from the current system in favor of greater economic rationality, decentralization, and flexibility. Whether scholars favor the current system or reject it in favor of some reform, however, the concept of standard-setting provides the starting point for analysis.

The essential picture of regulation in much of the environmental literature is that Congress passes a law, federal agencies implement the program (usually through rulemaking), and compliance follows in due course. Of course, everyone knows that this is not the whole story, because sometimes there is slippage along the way. Still, this is the paradigm, and much effort is devoted to attacking, defending, or reforming it.

This picture undoubtedly contains much truth and deserves the serious attention it has received. Nevertheless, it is strikingly incomplete. From the point of view of the practicing lawyer, it may seem almost irrelevant, except for the few who practice inside the Washington beltway where basic policy decisions about standards are made. Indeed, this conventional picture seriously distorts the realities of the present system. Slippage between regulatory standards and the actual conduct of regulated parties is far from being a peripheral element of the legal regime. What environmental lawyers do much of the time could be considered "slippage management." It could almost be said-admittedly, with some

U. CHr. L. REv. 1423 (1996).

6. See Robert Glicksman \& Christopher H. Schroeder, EPA and the Courts: Twenty Years of Law and Politics, 54 LAW \& CoNTEMP. ProBs. 249 (1991); Mark Seidenfeld, Demystifying Deossification: Rethinking Recent Proposals to Modify Judicial Review of Notice and Comment Rulemaking, 75 TEx. L. REv. 483 (1997); Peter L. Strauss, Revisiting Overton Park: Political and Judicial Controls Over Administrative Actions Affecting the Community, 39 UCLA L. REv. 1251 (1992).

7. For the classic debate on this issue, compare Howard Latin, Ideal Versus Real Regulatory Efficiency: Implementation of Uniform Standards and 'Fine-Tuning' Regulatory Reforms, 37 STAN. L. REv. 1267 (1985) (supporting conventional regulation) with Bruce A. Ackerman \& Richard B. Stewart, Reforming Environmental Law, 37 STAN. L. Rev. 1333 (1985) (arguing for incentive methods). For useful reviews of the more recent literature, see David M. Driesen, Is Emissions Trading an Economic Incentive Program?: Replacing the Command and Control/Economic Incentive Dichotomy, 55 WASH. \& LEE L. REv. 289 (1998); Nathaniel O. Keohane et al., The Choice of Regulatory Instruments in Environmental Policy, 22 HARV. ENVTL. L. Rev. 313 (1998).

8. See Daniel C. Esty, Revitalizing Environmental Federalism, 95 Mich. L. Rev. 570 (1996); Daniel A. Farber, Environmental Federalism in a Global Economy, 83 VA. L. Rev. 1283 (1997); Richard L. Revesz, The Race to the Bottom and Federal Environmental Regulation: A Response to Critics, 82 MinN. L. Rev. 535 (1997). 
exaggeration-that what the standard description characterizes as slippage is actually the primary feature of the system: the so-called standards are important only because they help channel the informal interactions between agencies and regulated parties.

This Article presents an alternate view of environmental law, one that highlights the slippage. The alternate picture does not resolve all of the policy questions raised above, but it does suggest a different perspective on some and raise additional questions of its own. It is not intended to replace the conventional picture but rather to supplement it, by directing attention at some neglected aspects of the system. ${ }^{9}$ Going beyond the conventional picture has implications for both teaching and scholarship in environmental law.

Part I discusses two forms of slippage. "Negative" slippage is a feature of environmental law so ubiquitous that we take it for granted: something that is legally mandated simply fails to happen. Deadlines are missed, standards are ignored or fudged, enforcement misfires. ${ }^{10}$ This is such a commonplace phenomenon that it becomes almost invisible; naturally, we are more likely to focus our attention on what is happening than on what isn't. We also fail to notice the processes that take the place of the mandated standards, such as ad hoc permitting: something is being done, even if it is not what Congress planned."1

"Affirmative" slippage is more interesting: the required standards are renegotiated rather than ignored, resulting in a regulatory regime that may bear little resemblance to the "law on the books." A current example is given by the Clinton Administration's revamping of the Endangered Species Act ("ESA"), reading an obscure escape clause (permits for incidental takes) so broadly that it now threatens to eclipse the rest of the statute. ${ }^{12}$ Often, as in the ESA example, these creative revisions involve intense negotiation between stakeholders rather than the execution of conventional regulatory mandates. Affirmative slippage seemingly is becoming more common, as the renegotiation process has become an in-

9. A full picture would have to incorporate both the standard view and its alternate. In particular, this Article should not be taken as denying either the genuine environmental progress that has been achieved under these statutes, or the fact that many actors do comply, often at considerable expense.

10. These compliance problems are by no means hidden, and are probably wellknown to anyone with even a small familiarity with the field. Even twenty years ago, it was clear that regulatory standards were often merely targets rather than strict mandates. See James A. Henderson, Jr. \& Richard N. Pearson, Implementing Federal Environmental Policies: The Limits of Aspirational Commands, 78 Colum. L. Rev. 1429 (1979). But to a surprising degree, we have managed to focus our attention elsewhere, thereby sustaining a state of denial regarding the extent of the compliance shortfall.

11. Thus, although we are accustomed to think of noncompliance as simply creating a blank space on the regulatory picture, there are few true vacuums in today's regulatory state: where the mandated standard is not successfully implemented, some other set of requirements is likely to hold sway instead.

12. See infra text accompanying notes 49-53. 
creasingly attractive alternative to conventional standard-setting. ${ }^{13}$ Prominent examples exist as early as the mid-1970s.

Part II explores how the concept of slippage might inform our discussions of legal doctrine, environmental policy, and environmental pedagogy. With respect to doctrine, it turns out that the Supreme Court has had a certain degree of complicity in the creation of slippage. If the amount of slippage in the current system is higher than we would like, some of those doctrines might be ripe for reappraisal. Slippage also has implications for policy debates over environmental standards. If standards are not automatically translated into compliance, our understanding of their costs and benefits may shift. Finally, in terms of teaching, we need to devote more attention to compliance-related issues. We also need to find ways of showing students how slippage may provide opportunities for creatively renegotiating environmental rules.

Of course, genuine compliance is also an important part of the overall scheme of environmental law. (A glass that is half empty must also be half full. ${ }^{14}$ ) But we seriously misunderstand the regulatory system if we ignore the pervasive effect of compliance issues on the system as a whole. The problem of obtaining compliance-and sometimes, even knowing what "compliance" means-is pervasive. Regulatory slippage is as central to environmental law as water resistance is to aquatic life-a ubiquitous condition that limits efforts at movement and shapes the design and development of everything it surrounds. It deserves much more attention than it has received.

\section{The ANatomy of Slippage}

In a well-ordered society, presumably, the law on the books would generally correspond with observed conduct, apart from the inevitable shortfall due to human error or antisocial motivations. In environmental law, however, shortfalls are widespread at all levels of the system, for reasons that cannot simply be attributed to antisocial or deviant conduct. This section documents some of the more notable examples.

13. "Affirmative slippage" has a complex relationship with formal mandates. Sometimes they are merely stretched; other times violated altogether. To complicate the picture further, sometimes the formal mandates are amended to fit the non-complying behavior. Some examples of these permutations can be found in Part I(B).

14. In particular, the considerable achievements of the regulatory system cannot be denied. See, e.g., Benefits of Regulations Outweigh Costs by at Least \$34 Billion, OMB Report Says, 29 Env't Rep. (BNA) 847 (1998). Indeed, one purpose of this Article is to focus more attention on how the significant obstacles to implementation have been at least partially overcome. 


\section{A. Negative Slippage}

If compliance consists of behaving according to law, the most obvious alternative is a simple failure to do so, in whole or in part. ${ }^{15}$ For instance, a statute may mandate that EPA issue certain regulations by a certain date, but EPA fails to meet the deadline (and perhaps fails to implement the requirement at any later time). Or a state government's regulatory program may be required to meet federal standards but fail to do so. Or, perhaps most obviously, a regulated party may fail to achieve the legally mandated level of environmental quality. As we will see, all three varieties of negative slippage are endemic.

\section{Failure to Act by Federal Regulators}

Congressional regulatory mandates follow a notorious pattern. A new statute or amendment is passed, with much fanfare. EPA or some other regulator is directed to issue new rules before some deadline, usually less than a year away. The time comes and goes, but no EPA action is forthcoming. Often the task cannot feasibly be completed on schedule, perhaps because of insufficient information or budget shortfalls. Sometimes EPA simply chooses not to comply because it believes the mandate is unworkable or would have politically unacceptable consequences.

For instance, under $\S 304(\mathrm{~b})$ of the Clean Water Act, ${ }^{16}$ passed in 1972, EPA was required to issue effluent guidelines no later than October 18,1973 . These guidelines were to form the basis for effluent limitations under $\$ 301$, which in turn had deadlines as early as 1977 , with a 1983 deadline for stricter standards. ${ }^{17}$ But the task proved to be far beyond EPA's capabilities, and the agency fell far behind schedule. For example, EPA did not promulgate final water pollution regulations for the organic chemicals, plastics, and synthetic fibers industry until $1987 .{ }^{18}$ Regulations for certain mining operations were issued in 1988, and upheld two years later. ${ }^{19}$ Thus, these particular standards were at least fifteen years overdue. As a result of such delays, many permits were issued in the meantime without the benefit of the mandated EPA regulations. Under the statute, until these regulations are in place, permits are to be issued under "such conditions as the Administrator determines are necessary to carry out the provisions of this chapter." ${ }^{20}$ The result was, in practice, the

15. Negative slippage seems to have been the core policy of the early Reagan EPA. See RODGERs, supra note 2 , at 536 (describing hazardous waste regulation under Administrator Anne Gorsuch).

16. 33 U.S.C. $\S 1314(b)$ (1994).

17. 33 U.S.C. $\$ 1331$ (b) (1994). In practice, EPA merged the $\$ 304$ guidelines with $\$ 301$ effluent limitations, which could be considered a kind of slippage as well.

18. See 18 Env't Rep. (BNA) 1736 (Nov. 13, 1987).

19. See Rybachek v. Alaska Miners Ass'n, 904 F.2d 1276 (9th Cir. 1990).

20. 33 U.S.C. $\$ 1342(a)(1)(B)(1994)$. 
imposition of pollution requirements largely unrelated to the apparent demands of the statute:

Congress wanted technology-based standards to apply uniformly to similar sources across the nation, but the permits were negotiated on an individualized basis incorporating whichever control measures and compliance schedules dischargers would accept. EPA characterized these permits as grounded on "best professional judgment;" but they often reflected simply the "best deal" the Agency could obtain in light of manpower and time constraints and its desire to demonstrate progress. These "best professional judgments" were usually made by EPA regional personnel with water quality, not technology-based, orientations. Thus, many control measures imposed in the permits bore little resemblance to the technologybased requirements mandated by the statute. ${ }^{21}$

This situation did not come to an end when the $\S 301$ standards were finally forthcoming. Even today, according to a recent General Accounting Office ("GAO") report, "there is no real consistency in how pollutant levels are set in ... permits."22

Similar stories can be told about other environmental statutes. ${ }^{23}$ EPA has apparently sometimes found it preferable to leave certain mandates unimplemented. For instance, the agency doggedly refused to implement the original provision of the Clean Air Act regulating toxics, because it considered the provision unworkably draconian. ${ }^{24}$ More generally, in the

21. Howard Latin, Regulatory Failure, Administrative Incentives, and the New Clean Air Act, 21 ENVTL. L. 1647, 1672 (1991).

22. Victor B. Flatt, A Dirty River Runs Through It (The Failure of Enforcement in the Clean Water Act), 25 B.C. EnvTL. AfF. L. Rev. 1, 17 (1997). In another deviation from the statutory scheme, EPA has failed to make "best available technology economically achievable" ("BAT") standards significantly stricter than the "best practicable control technology currently available" ("BPT") standards discussed in the text. See Oliver Houck, Of Bats, Birds, and B-A-T: The Convergent Evolution of Environmental Law, 63 Miss. L.J. 403, 452 (1994).

23. Even successful litigation may not succeed in securing significant compliance:

When the Sierra Club sued the EPA for not promulgating [radionuclide] regulations by a statutory deadline, ... organization experts hastily issued the regulations without letting its Science Advisory Board review them. When the latter finally did, it found them scientifically flawed. The EPA Administrator responded by withdrawing the regulations and was held in contempt of court. To purge itself of the contempt-of-court citation, the organization then issued "sham" regulations that conformed with the letter of the court's order but in fact increased the amount of radionuclides that could be emitted into the atmosphere.

ROSEMARY O'Leary et al., MANAGING FOR THE ENVIRONMENT: UNDERSTANDING THE Legal, ORganizational, and Policy Challenges 275 (1998). 233 (1990).

24. See John P. Dwyer, The Pathology of Symbolic Legislation, 17 Ecology L.Q. 
early years of the Act, EPA regional offices "issued hundreds of administrative orders and compliance schedules" that "diverged" from legal requirements and were "more lenient than necessary to reach attainment."25 EPA was similarly recalcitrant about enforcing important provisions of the statute dealing with transboundary pollution. ${ }^{26}$

\section{Noncompliance by State Regulators}

Environmental statutes often call for states to assume enforcement authority, subject to federal supervision. In reality, the supervision is often lax, and states often are able to deviate openly from statutory requirements. The "threat of EPA withdrawing approval for any state enforcement programs and having the federal government assume primary responsibility" is "hollow due to a lack of federal resources and an expanding number of regulated entities."27

For instance, EPA has admitted its unwillingness to impose strict deadlines or sanctions on state agencies regulating air pollution. ${ }^{28}$ As John Dwyer has explained, there are strong pressures against the full exercise of federal authority in this area, because a "successful federal air pollution control program requires the willing participation of state administrative agencies." 29 Thus, according to Dwyer:

[T]here are practical administrative and political limits to centralization. Although it has as much legal authority as it needs, the federal government cannot implement its air pollution program without the substantial resources, expertise, information, and political support of state and local officials. Congress and EPA can quell minor revolts among state agencies, but widespread dissatisfaction-manifested in the time-honored "go-slow" approach-will bring EPA and even Congress to the bargaining table..$^{30}$

As a result, Dwyer says, "the states have been able to work compromises with EPA rather than be slavishly subject to federal dictates." 31

25. Latin, supra note 21 , at 1689.

26. See Thomas W. Merrill, Golden Rules for Transboundary Pollution, 46 DUKE L.J. 931, 984 (1997).

27. Flatt, supra note 22, at 31 . For example, the only time EPA has seriously threatened to withdraw program approval under the Resource Conservation and Recovery Act ("RCRA") was because the state program was too strict. See RoDGERs, supra note 2, at 643.

28. See Latin, supra note 21 , at 1691.

29. John P. Dwyer, The Practice of Federalism Under the Clean Air Act, $54 \mathrm{MD} . \mathrm{L}$. REv. 1183, 1218 (1995). Dwyer's account of the inability of EPA to obtain state compliance with requirements for "inspection and maintenance" programs is particularly striking. See id. at 1208-16.

30. Id. at 1224.

31. Id. at 1216 . 
Similarly, under the Clean Water Act, states have found it possible to dodge or disobey federal mandates outright. As the GAO found, one state refused to apply new federal standards simply because it found them to be too strict, but "EPA did not withdraw the program because it was 'an unrealistic option'."32 States are at best uneven in their implementation of the statute. For instance, sources in one state were allowed to remain out of compliance for about fifty percent longer than those in another state. ${ }^{33}$ Indeed, EPA lacks the essential information it would need to monitor state programs effectively even if it had the desire to do so. $^{34}$ The desire itself, however, is often lacking. For instance, EPA colluded with the states for many years to avoid implementing the "total maximum daily load" requirements of the Act. Only after a series of successful citizen suits by environmentalists were compliance efforts belatedly undertaken by federal and state agencies..$^{35}$

\section{Noncompliance by Regulated Parties}

It would be a travesty to say that the federal environmental statutes are a dead letter. But it is equally obvious that translating legal mandates into actual compliance is far from automatic. Under the Clean Air Act, the nation was supposed to have achieved the primary national air quality standards by 1975 . Two years after the supposed deadline had been missed, Congress amended the statute and extended the deadline to 1982 (or 1987 for some pollutants). When these deadlines arrived, EPA was placed in an embarrassing position. For instance, over seventy cities missed the 1987 deadline for ozone and carbon monoxide. EPA managed to put off any serious sanctions until Congress passed the 1990 amendments, again postponing the compliance dates. ${ }^{36}$ After 1990, a new cycle of mandates, delay, and partial compliance began. ${ }^{37}$

Noncompliance has also been a serious problem with respect to water pollution. For example, some twenty years after the passage of the Clean Water Act, roughly 10,000 dischargers still had no permits whatsoever, ${ }^{38}$ twelve to thirteen percent of major private and municipal sources were in a "Significant Noncompliance" status during a single

32. Flatt, supra note 22 , at 18.

33. See id. at 26. The two states were Georgia and Washington. On uneven state enforcement, see also Nicholas Yost, The State of Environmental Law Enforcement: A Speech Presented at the American Bar Association's Annual Meeting, 28 Envtl. L. Rep. (Envtl. L. Inst.) $10,711,10,712$ (1998).

34. See Flatt, supra note 22, at 18-19.

35. See Oliver Houck, TMDLs III: A New Framework for the Clean Water Act's Ambient Standards Program, 28 Envtl. L. Rep. (Envtl. L. Inst.) 10,415, 10,416 (1998).

36. See Roger W. Findley \& DaNiel A. Farber, Cases AND MATERIals on ENVIRONMENTAL LAW 365-66 (5th ed. 1999).

37. See id. at 367-68. (1993).

38. See Robert W. Adler et al., The Clean Water Act: 20 Years later 151 
three-month period alone, and another five percent of industrial sources avoided that status only because they were already on extended compliance schedules. ${ }^{39}$ The situation was even worse for companies discharging into sewage systems rather than waterways: thirty-five percent were in "significant" violation of discharge standards ${ }^{40}$ Even the more optimistic estimates of compliance are in the seventy-five percent range, which is not at all discreditable but does mean that a quarter of sources are noncomplying in some respect. ${ }^{41}$

More recently, EPA's Inspector General documented widespread breakdowns in enforcement, even by the agency itself. For instance, in two states, federal authorities "had not issued or renewed hundreds of permits required for factories and waste water treatment plants, often for as long as ten years. ${ }^{.42}$ In recent years, EPA's Seattle office had written thirty-three permits, but there was a backlog of a thousand applications, most of them over four years old. Compliance by state agencies was also spotty. In one state, about half of major air pollution sources were never inspected. For two years, the state completely stopped reporting major violations (contrary to federal law), and even after being rebuked by EPA, the state complied only partially. ${ }^{43}$

As noted earlier, there is probably always a gap between the law on the books and the law in action. In environmental law, at least, it seems to be perilous to assume that the two will correspond. Unfortunately, we have devoted disproportionate attention to the former, without enough attention to the mechanisms that translate it into the latter.

\section{B. Positive Slippage}

In the previous subsection, we considered slippage in the most straightforward sense of something falling behind something else. But more interesting possibilities also exist. Rather than slipping "behind," implementation can instead slip "sideways" or sometimes even "forward" vis $a$ vis the formal standards. We will discuss three scenarios. In the first, the result of slippage is a de facto (and sometimes ultimately de jure) modification in the regulatory standards themselves. That is, the agency follows the normal procedures for setting standards, but the sub-

39. See id. at 167.

40. Id. at 147.

41. See Mark Cohen, Monitoring and Enforcement of Environmental Policy 4 (Aug. 1998) (unpublished manuscript, on file with author). Cohen also reports that "[u]ntil recently, the U.S. EPA did not have comprehensive compliance data available themselves, let alone make it available to researchers." Id. at 32.

42. John Cushman, EPA and States Found to Be Lax on Pollution Law, N.Y. Trmes, June 7, 1998, at 1 . The two states were Idaho and Alaska.

43. See id. at 17 (reporting data from New Mexico). For further comments on regional variations in enforcement levels, see Yost, supra note 33. 
stance of the decision diverges from statutory requirements. In the second; the standard setting process itself is displaced by some kind of negotiated agreement, sometimes encompassing federal and state regulators as well as regulated parties. In the third scenario, the slippage occurs during the enforcement stage, when individual sources are faced with sanctions of some sort.

Positive slippage falls uneasily between compliance and noncompliance. By definition, it does not follow the apparent thrust of the underlying mandate. But positive slippage may have at least some colorable legal validity, and where even that is lacking, Congress sometimes steps in after the fact to provide its imprimatur.

\section{Morphing Standards}

A classic example of the first scenario is provided by the history of toxics regulation under the Clean Water Act. As enacted in 1972, the statute required EPA to promulgate standards providing an "ample margin of safety" for all toxic water pollutants. This section was never implemented as written, in part because it would have resulted in widespread plant closings. EPA was sued for its failure to implement the toxics program, and entered into a settlement. But the consent decree did not call for regulation under the "ample margin" standard mandated by the statute. Instead of basing regulations purely on risk levels, as the statute required, the consent decree required EPA to issue regulations based on the best available technology for various industries. Thus, riskbased standards were replaced, via the consent decree, with technologybased standards. ${ }^{44}$ This was a somewhat startling rewrite of the statutory standards by way of litigation, but received Congress's approval a few years later when the statute was amended to incorporate the main provisions of the consent decree..$^{45}$

Another interesting example from the same era involved mobile source standards under the Clean Air Act. In International Harvester Co. v. Ruckelshaus, ${ }^{46}$ the court vacated EPA's refusal to grant waivers to the leading car companies. Although the statute squarely placed the burden on the companies to show that pollution control technology was unavailable, the court in effect switched the burden of proof, requiring EPA to show that compliance was feasible. The rationale was that the economic disruption that would result from denial or postponement of relief to the

44. See Ridgway M. Hall, Jr., The Clean Water Act of 1977, 11 NAT. REs. LAWYER $343,351-53$ (1978).

45. 33 U.S.C. $\& 1317$ (a)(2) (1994) (first sentence). Because the amendment was not entirely identical with the consent decree, the consent decree was held not to be superseded. See Envtl Defense Fund v. Costle, 636 F.2d 1229 (D.C. Cir. 1980).

46. 478 F.2d 615 (D.C. Cir. 1973). 
industry outweighed the environmental consequences of a waiver. ${ }^{47}$ On remand, the EPA essentially took the court's hint to ignore the statutory criteria for waivers. Instead, EPA adopted a clever alternative approach, relaxing the national standards for automobile pollution (as requested by the manufacturers) but using its power under another provision to authorize California to impose a more rigorous standard ${ }^{48}$ In effect, at the court's prompting, EPA had revamped the statutory scheme to make national variances readily available, but put pressure on manufacturers for continued progress by requiring cleaner cars for the California market.

\section{Renegotiating Regulations}

The Clinton Administration has shown particular interest in renegotiating regulatory standards. Perhaps the most notable example is provided by the Endangered Species Act. As originally enacted, the statute was an all but absolute ban on destruction of individual members of endangered species. ${ }^{49}$ But this ban led to what seemed to be an untenable situation, in which individual landowners were faced with bans on development to save the last few members of a species, while the government seemed powerless to intervene at an earlier time to protect the habitat on which the species relied. ${ }^{50}$ An obscure 1982 Amendment proved to be the key to the solution. The amendment allowed the Secretary of the Interior to issue a permit to "take" members of an endangered species (e.g., by modifying their habitat), provided that the taking is incidental to the project, all possible mitigation measures are used, and there will be no appreciable effect on the prospects of the species for survival. ${ }^{51}$ Someone whose only source of information was the statute itself could be pardoned for believing that this was a minor exception, probably aimed at situations where legitimate hunting or fishing activity posed some risk of accidental harm to members of endangered species. But in fact, the provision has served as the basis for a sweeping new approach to protecting endangered species.

47. For discussions of this influential opinion, which made only a thin pretense of complying with the statute, see Daniel Farber, Statutory Interpretation and Legislative Supremacy, 78 Geo. L.J. 281, 298-300 (1989); David Schoenbrod, Goal Statutes or Rules Statutes: The Case of the Clean Air Act, 30 UCLA L. REv. 740, 786 (1983).

48. For a discussion of this history and later developments, see FINDLEY \& FARBER, supra note 36 at 269.

49. See Tenn. Valley Auth. v. Hill, 437 U.S. 153 (1978) (holding that federal action endangering species must be enjoined regardless of countervailing government interests).

50. See Blaine Green, The Endangered Species Act and Fifth Amendment Takings: Constitutional Limits of Species Protection, 15 YALE J. ON REG. 329 (1998).

51. See 16 U.S.C. \$ 1539(a)(2)(A) (1994). Notably, the Habitat Conservation Plan ("HCP") concept derives from an earlier effort to negotiate an informal solution to a specific dispute without any express statutory authorization. See Alejandro Camacho, The San Bruno Habitat Conservation Plan 5-7 (May 1998) (unpublished manuscript on file with the author). 
For instance, the habitat conservation plans for Southern California cover a 39,000 acre tract in coastal Orange County and over 150,000 acres in the San Diego area. ${ }^{52}$ As the Southern California plan was described by the responsible federal official:

In this experiment most of the remaining open space in San Diego, Orange, and Riverside County is being planned and allocated. The process involves the State of California, the counties, half-a-dozen cities, large landowners, environmental groups, and the U.S. Fish and Wildlife Service (USFWS), who are cooperatively developing regional habitat plans designed to protect not only listed endangered species but other rare species and their habitats, as well as open space, clean water, and recreational values.

What triggered these vast planning efforts in California? In the summer of 1993, the USFWS was preparing to list the California gnatcatcher, a coastal bird, as an endangered species. Unfortunately, the gnatcatcher's coastal sage habitat is also the last remaining prime development land in Southern California; it is much sought for subdivisions and shopping centers. In response to this dilemma, we promulgated a "special rule" under the ESA that proposed delegation to the State and counties of Southern California the responsibility for determining how to conserve gnatcatcher habitat. Instead of federal biologists telling thousands of private landowners on a case-by-case basis what they could and could not do on particular parcels of land, the rule allows the state and counties to develop comprehensive science-based plans guaranteeing that enough habitat would be conserved on a regional basis over the next 100 years. If the Department approves these plans, they will be implemented in lieu of the normal Endangered Species Act regulations. ${ }^{53}$

Perhaps the most revealing assertion in this passage is the casual closing remark that the negotiated agreement will be "in lieu of the normal Endangered Species Act regulations."

Another important recent example of regulatory renegotiation is provided by the recent agreement of the automobile industry to introduce, ahead of the statutory deadline, a new level of pollution control in cars sold across the country. This concession arose out of complex negotiations between multiple parties: the industry; environmentalists; the Northeast States, who were threatening to invoke their powers under another portion of the statute to deal with regional ozone problems; the

52. See William K. Stevens, Salvation at Hand for a California Landscape, N.Y. Times, Feb. 27, 1996, at C8.

53. George Frampton, Ecosystem Management in the Clinton Administration, 7 DuKe EnvtL. L. \& PoL'Y F. 39, 41-42 (1996). 
State of California, which plays a pivotal role with respect to regulating car pollution; and the EPA. ${ }^{54}$

These examples are part of a much broader EPA effort to "reinvent" environmental regulation. 55 The best known example is Project $\mathrm{XL}$, in which the agency attempted to negotiate with individual sources to reduce their net environmental impact below what could be achieved by full compliance with existing regulatory standards. As described by some early enthusiasts:

If coupled with the legislation that is necessary to achieve its purposes, Project XL has the potential to make truly revolutionary changes in the way companies are regulated in the United States. Once the program is in place, individual companies will create pilot projects from the bottom up that will be based on performance standards rather than the more stifling "one size fits all" technology based controls. These projects are anticipated to foster technological innovation and reduced compliance costs while resulting in greater pollution prevention. Participating facilities will be able to use multimedia approaches and market-based controls in realizing the performance-based standards. ${ }^{56}$

More simply, the idea is to excuse some supposedly less significant regulatory violations in exchange for agreements to transcend the standards in more important respects-thus the motto, "If it isn't illegal, it isn't XL." 57

\section{Creative Enforcement Measures}

The environmental statutes provide a battery of enforcement measures including injunctions, civil penalties, and criminal sanctions. ${ }^{58} \mathrm{EPA}$ has created another enforcement measure, the Supplemental Environmental Project ("SEP"). A SEP is an environmentally desirable measure that a violator agrees to implement in place of some of the penalty which

54. See Taly Jolish, Negotiating the Smog Away: How the Northeast States, the Automakers, and EPA Developed the National Low Emission Vehicle Program (Apr. 29, 1998) (unpublished manuscript, on file with author).

55. For a description of these efforts (and their debatable validity under current law), see Bradford C. Mank, The Environmental Protection Agency's Project XL and Other Regulatory Reform Initiatives: The Need for Legislative Authorization, 25 ECOLOGY L.Q. 1 (1998).

56. Beth S. Ginsberg \& Cynthia Cummis, EPA's Project XL: A Paradigm for Promising Regulatory Reform, 26 Envtl. L. Rep. (Envtl. L. Inst.) 10,059, 10,060 (1996).

57. Rena I. Steinzor, Regulatory Reinvention and Project XL: Does the Emperor Have Any Clothes, 26 Envtl. L. Rep. (Envtl. L. Inst.) 10,527 (1996). For a more favorable view of XL, see Ginsberg \& Cummis, supra note 56.

58. For a useful history of EPA enforcement, see generally JOEL A. MINTZ, ENFORCEMENT AT THE EPA: High STAKES AND HARD CHOICES (1995). 
it would otherwise be legally required to pay. From 1992 to 1994, EPA negotiated more than 700 SEPs, with an estimated cost exceeding $\$ 190$ million. A case study of ten SEPs found some significant pollution prevention efforts. ${ }^{59}$

Settlements have also been used in imaginative ways in private litigation. Under the Clean Water Act, citizens may sue to collect civil penalties payable to the government. In settlements, however, instead of payments of fines to the government, environmental groups have obtained agreements to use funds, in several cases exceeding $\$ 1$ million, ${ }^{60}$ for mitigation projects. This practice now has explicit recognition in the citizen suit provision of the Clean Air Act, which provides that penalties may be applied to mitigation projects rather than being paid to the government. ${ }^{61}$ It is particularly significant that here, as in some of the examples discussed earlier, what appeared to be slippage was later partially ratified by Congress. This phenomenon helps account for the ambiguous

59. See Charles C. Caldart \& Nicholas A. Ashford, Negotiation as Means of Developing and Implementing Environmental Policy, 23 HARv. ENVTL. L. Rev. 141, 190 (1999). As Caldart and Ashford explain:

So long as the penalty does not fall below the acceptable minimum, EPA will (depending on the assessed merits of the project) credit up to eighty percent of the after-tax cost of most approved SEPs (net of any savings, such as reduced operations costs, that the SEP may offer to the violator) against the amount of the penalty. In order to encourage certain types of projects, however, the agency revised its policy in 1995 to offer a credit of up to $100 \%$ for SEPs judged to be "of outstanding quality" according to a set of specified criteria ....

EPA reports that, between Fiscal Years 1992 and 1994, it negotiated more than 700 SEPs. Of these, approximately fourteen percent were pollution prevention SEPs, with an estimated total value of approximately $\$ 57$ million. EPA estimates that these pollution prevention SEPs will reduce the discharge of toxic chemicals and the production of hazardous waste by a total of some 65 million pounds.

Id. (citations omitted). Richard Lazarus is now conducting a large-scale study of SEPs, which should tell us considerably more about their use. Interview with Richard Lazarus, Professor of Law, Georgetown University, in Cambridge, Mass. (Nov. 21, 1998). There is some reason for concern that the use of SEPs may undermine deterrence. See David A. Dana, The Uncertain Merits of Environmental Enforcement Reform: The Case of Supplemental Environmental Projects, 1998 Wis. L. Rev. 1181, 1184.

60. See Scott M. DuBoff, The 1990 Amendments and Section 304: The Specter of Increased Citizen Suit Enforcement, 7 NaT. RES. \& ENV'T. 34 (1992). Creative remedies have long placed judges in a policymaking role in some types of public law litigation such as school desegregation and prison reform cases. See Colin S. Diver, The Judge as Political Powerbroker: Superintending Structural Change in Public Institutions, 65 VA. L. REv. 43 (1979). Settlements in mass torts cases have also served, in effect, as methods for law reform, revamping the normal rules of tort law in establishing novel standards for compensating claimants. See Jay Tidmarsh, Mass Setrlement Class Actions: Five Case STUDIEs 6-8 (1998). For a notable environmental example, see RoDGERS, supra note 2, at 288. Another example is provided by the recent national tobacco settlement, which imposes substantial restrictions on industry activities. See Settlement with Tobacco Industry Bans Most Advertising, Trade Groups, 67 U.S.L.W. 2312 (Dec. 1, 1998).

61. 42 U.S.C. \& 7604(g)(2) (1994). 
legitimacy of slippage: even conduct that seems dubious at the time in formal terms, may be "baptized" after the fact.

\section{The IMPLications of SlipPage}

\section{A. Slippage and Legal Doctrine}

Some degree of slippage is inevitable in any legal regime. In the environmental regime, some additional forces are at play, including the notorious propensity of Congress to pass unrealistic or symbolic statutes that invite an exceptional degree of slippage. But the Supreme Court has also played a role in encouraging slippage. It has created doctrines that increase the difficulty of holding federal agencies to their statutory mandates and that make it harder for Congress and federal agencies to control state regulators. The Court has also given regulated parties more room for noncompliance through rulings that have softened enforcement mechanisms. In part, these decisions may be motivated by a realistic appreciation of the inevitability of slippage in environmental law. At the same time, the Court has also (perhaps unwittingly) reinforced the tendency of the system toward slippage. This practical effect is significant, and may be unfortunate on balance, though the larger question of whether these doctrines should be revisited is beyond the scope of this Article.

\section{Giving Regulators Slack}

The Supreme Court has given federal agencies more room to deviate from statutes through two doctrinal innovations. The first is the Chevron doctrine, which makes it harder to challenge agency noncompliance on the merits. The second is the Court's contraction of standing doctrine, which makes it harder for challengers to get into court in the first place. ${ }^{62}$

The likelihood that an agency can successfully avoid compliance is inversely related to the strictness with which its legal position will be reviewed in court. The Chevron doctrine ${ }^{63}$ diminishes the threat of overturning the agency's legal interpretation. Except when the agency's position is clearly incompatible with the statutory text (or perhaps, clear legislative history), Chevron requires courts to defer to any "reasonable" interpretation by the agency. Although it is hard to document the extent

62. In addition, the Court has sided with agencies in every decided National Environmental Policy Act ("NEPA") case, thereby reducing the constraints that the statute places on agencies. See Daniel Farber, Environmental Law: Disdain for 17-Year-Old Statute Evident in High Court's Rulings, NAT'L L.J., May 4, 1987. (1984).

63. Chevron, U.S.A. v. Natural Resources Defense Council, 467 U.S. 837, 866 
to which Chevron has increased judicial deference in operational termspartly because prior law also provided some degree of deference to agencies $^{64}$-in at least some close cases the Supreme Court's counsel of deference must tip the balance in favor of an agency. By increasing the burden on challengers, Chevron increases the likelihood that a court will erroneously uphold a dubious agency action. Thus, for an agency that is considering stretching a statute (perhaps to the breaking point), Chevron provides an additional margin of comfort.

Recent standing decisions also provide agencies with more breathing space. In a series of recent opinions, the Court has made it more difficult for challengers (particularly environmentalists) to attack potentially unlawful agency actions..$^{65}$ If no one has standing to challenge an agency's decision, the extent of the agency's compliance with its legal mandate becomes a non-issue from a tough-minded lawyer's point of view, although bureaucrats may still have oversight hearings to contend with. Indeed, this effect of the Court's recent standing decisions is not entirely coincidental. Justice Scalia, the prime mover behind the opinions, suggested before his elevation to the bench that some statutes are not really meant to be universally enforced and implied that justiciability doctrine: should provide leeway for a certain degree of agency flexibility. ${ }^{6}$

The Court has also given state regulators more space for noncompliance through its recent federalism decisions, which make it more difficult for the federal government to hold the states accountable. If a state ignores the various carrots and sticks incorporated into statutes, the ultimate sanction would be a direct mandate to state officers. But in New York $v$. United States ${ }^{67}$, the Court blocked this ultimate sanction, ruling that the federal government lacks the power to "commandeer" state

64. See, e.g., E.I. Du Pont De Nemours \& Co. v. Train, 430 U.S. 112 (1977); Train v. NRDC, 421 U.S. 60 (1975).

65. See Lujan v. Defenders of Wildlife, 504 U.S. 555 (1992); Lujan v. Nat'1 Wildlife Fed'n, 497 U.S. 871 (1990); see also Ohio Forestry Ass'n v. Sierra Club, 523 U.S. 726 (1998) (using ripeness doctrine to block challenge to forest service management plans); Steven Quarles \& Thomas Lundquist, The Supreme Court Restricts the Availability of Forest-Wide Judicial Review in Ohio Forestry Ass'n v. Sierra Club, 28 Envtl. L. Rep. (Envtl. L. Inst.) $10,621,10,630$ (1998) (Court's decision "changes the rules for judicial review of national forest decisions" and "exemplifies the theme expressed in Lujan v. NWF that many programmatic issues should not be heard by the courts"). Even if we assume that noncompliance is undesirable, however, these decisions may have off-setting positive benefits. See Ann E. Carlson, Standing for the Environment, 45 UCLA L. Rev. 931 (1998). Thus, their contribution to slippage is not in itself enough to condemn these decisions, but it may be enough to counsel a close second look at their reasoning.

66. See Antonin Scalia, The Doctrine of Standing as an Element of the Separation of Powers, 17 SUFFolK U. L. REv. 881, 894 (1983).

67. 505 U.S. 144 (1992). So important is this principle that the New York Court makes it an absolute rule, not subject to override by any government interest, no matter how weighty. This anti-commandeering principle thus seems to occupy a more central place in the Court's pantheon of values than rights such as freedom of speech and religion, which are subject to override in the presence of a compelling governmental interest. 
officers to implement federal statutes. Thus, Congress may seek to pressure or coerce the states into executing federal environmental law, but in the end, it has no remedy if the states are sufficiently determined to resist. Of course, this ultimate sanction would rarely be used in any event for practical reasons, but knowing that it is completely unavailable (and having the state's constitutional right to resist endorsed by the Supreme Court) makes state noncompliance that much easier.

\section{Creating Slack for Regulated Parties}

There is no reason to assume that the Court has consciously pursued such a strategy, ${ }^{68}$ but in three separate lines of decisions, it has given regulated parties more room for noncompliance. One line of decisions gives courts discretion to soften enforcement measures such as injunctions. A second line of decisions has limited the availability of citizen's suits, thereby weakening an important enforcement mechanism. The third line of decisions has made attorneys' fees less available, making it more difficult to pursue noncomplying parties of all kinds (federal, state, and private).

When confronted with on-going noncompliance with applicable law, one might expect the routine judicial response to be an order mandating compliance. It does, after all, seem odd for courts to countenance violation of the law by finding immediate compliance to be unreasonable. But the Supreme Court (without ever phrasing the question in this way), has recognized at least a limited power for courts to excuse on-going disobedience of the law. In Weinberger $v$. Romero-Barcelo ${ }^{69}$ the district court found that the Navy had violated the Clean Water Act by failing to obtain a discharge permit for certain activities. Although the Court did not question the view that the Navy was at least technically violating the law, it held that an immediate injunction against continuing to discharge without a permit was unnecessary. According to Justice White's majority opinion, "[t]hat the scheme [of the Clean Water Act] as a whole contemplates the exercise of discretion and balancing of equities militates against the conclusion that Congress intended to deny courts their traditional equitable discretion in enforcing the statute." ${ }^{30}$ Thus, at least to a

68. Indeed, I have previously expressed doubts about whether the Court's decisions reflect any coherent vision of environmental law. See Daniel Farber, Is the Supreme Court Irrelevant? Reflections on the Judicial Role in Environmental Law, 81 MiNN. L. REv. 547 (1997).

69. 456 U.S. 305 (1982). The Author is grateful to Richard Lazarus for pointing out the relevance of this line of cases.

70. Id. at 316. See also Amoco Production Co. v. Village of Gambell, 480 U.S. 531 (1987) (denying an injunction against violations of mandated procedures for offshore Alaskan oil leases, on the ground the environmental damage was unlikely and the injunction would interfere with the federal goal of increasing oil exploration). Similar issues arise under NEPA, where agency noncompliance may sometimes be in effect authorized by 
certain degree, courts seem to be authorized to at least give noncomplying parties a grace period, if not to excuse compliance indefinitely. ${ }^{71}$

Because of limits on the resources (and sometimes motivation) of government agencies to enforce the law, citizen suits have been an important environmental enforcement mechanism. The Supreme Court has issued several decisions making it more difficult to bring these suits. Apart from the standing-related decisions mentioned earlier, which sometimes block citizen suits, the Court has also imposed procedural barriers. It has held that compliance with the statutory notice requirements is a jurisdictional precondition to suit. It has also held that citizens cannot sue to force payment of civil penalties or collect attorney fees if the notice prompts voluntary compliance (or a settlement with state authorities) fully correcting the violation. ${ }^{72}$ The result of these decisions is to discourage groups from investing in citizen suits in the first place, since they will be unable to recover their expenses if the case aborts because of voluntary compliance or intervening action by state authorities.

Indeed, the Court has generally been unresponsive to the role played by attorney's fees in encouraging enforcement actions against both government and private actors. The Court has refused to allow such fees without explicit statutory authorization, ${ }^{73}$ and has read such authorizations narrowly: for instance, even when Congress deliberately avoided use of the term "prevailing party" as a qualification for fees, the Court read such a requirement into the statute. ${ }^{74}$ The Court has also refused to allow additional compensation when lawyers have prevailed in risky litigation, ${ }^{75}$ thereby discouraging litigants from pursuing such litigation.

Again, there is no reason to believe that the Court has consciously attempted to undermine compliance with environmental laws, and the fact that certain decisions may have had that effect does not by itself demonstrate that they were incorrectly decided. Nevertheless, the Court at least seems to have been fairly tolerant toward noncompliance, and this tolerance presumably has at least incrementally encouraged "foot

the courts. See Leslye A. Herrmann, Note, Injunctions for NEPA Violations: Balancing the Equities, 59 U. CHI. L. REv. 1263 (1992).

71. For further discussion, see Daniel Farber, Equitable Discretion, Legal Duties, and Environmental Injunctions, 45 U. PITT. L. REv. 513 (1984).

72. See Steel Co. v. Citizens for a Better Env't., 523 U.S. 83 (1998) (no Article III jurisdiction over wholly past violations); Hallstrom v. Tillamook County, 493 U.S. 20 (1989) (notice to state agencies and violators is jurisdictional precondition); Gwaltney of Smithfield, Ltd. v. Chesapeake Bay Found., Inc., 484 U.S. 49 (1987) (citizen suits are precluded for "wholly past violations").

73. See Alyeska Pipeline Service Co. v. The Wilderness Society, 421 U.S. 240 (1975). See also Key Tronic Corp. v. U.S., 511 U.S. 809 (1994) (refusing to read the Comprehensive Environmental Response, Compensation, and Liability Act ("CERCLA") as allowing such fees in the absence of explicit statutory language).

74. See Ruckelshaus v. Sierra Club, 463 U.S. 680 (1983). For a critique of the decision, see Farber, Statutory Interpretation, supra note 47, at 281, 300-02.

75. See City of Burlington v. Dague, 505 U.S. 557 (1992) (no enhancement for successful contingent fee cases permitted in RCRA suit). 
dragging" by both agencies and private actors. The concept of slippage provides a unifying perspective for considering this broad range of legal doctrines, as well as some ground for urging reconsideration.

\section{B. Slippage and Environmental Policy}

Understanding slippage also has implications for environmental policy. In the conventional view, regulatory standards serve a simple purpose: they determine the level and cost of environmental protection (with perhaps a small discount for noncompliance). But in the real world, as we have seen, the linkage is far from automatic: specific ground-level decisions may take place in the absence of standards (though under threat of future standards or potential liability), or in some negotiated deviation from the standards. Thus, rather than focusing on regulatory standards in isolation, we need to see them as part of a larger process of negotiation between government actors, industry, and environmentalists. Thus, we don't need to "reinvent regulation"-in some sense, what we would now regard as the "reinvented version" has been around us all along, for better or worse.

This section will consider how understanding slippage might better inform debates over how to set regulatory standards and over "reinventing" regulation. It closes with a discussion of how scholars might understand the causes and cures of slippage.

\section{Reevaluating the Standards Debate}

In assessing conventional regulation, the implicit assumption generally is that the regulatory standards will be fully implemented (or at least, that any shortfall in compliance is irrelevant in assessing the standards themselves). But to some degree, these analyses may be based on a misunderstanding of the actual function served by the supposed standards. As we have seen, compliance with standards is frequently delayed, incomplete, or even nonexistent. Thus, standards may commonly function as starting points in the lengthy interactions between agencies and regulated parties, rather than as end points of compliance. Often, so-called standards may serve as threat points in negotiation or as penalty defaults that force information disclosure. ${ }^{76}$ The optimum "standards" for these

76. An interesting body of scholarship treats penalty defaults in contract clauses as information forcing devices. See, e.g., Ian Ayres \& Robert Gertner, Filling Gaps in Incomplete Contracts: An Economic Theory of Contract Default Rules, 99 YALE L.J. 87 (1989); Jason Johnston, Strategic Bargaining and the Economic Theory of Contract Default Rules, 100 YaLE L.J. 615 (1990). This literature might have some lessons for environmental law, to the extent standards are functionally default rules subject to renegotiation. 
purposes may well be quite different from (and often harsher than) the ultimate performance level that we wish to attain.

To the extent this situation holds true-to the extent, that is, that slippage is widespread-it is far from clear that the standards themselves should reflect an optimum balance of compliance costs and environmental benefits. The fact that the standards are sometimes too harshthat they have compliance costs that are too high compared with benefitsmay be perfectly reasonable. In effect, the standards may merely be the government's opening demand in negotiations, and the final bargain is likely to be more favorable to the other side. If the government began the negotiations with an "optimal" regulatory demand (optimal in the sense that implementation would maximize net social benefits), the ultimate bargain would probably be too favorable to the regulated party. Thus, the criticism that regulatory standards are too harsh loses some of its force, once it is recognized that the standards are often only partially implemented.

Similarly, attacks on the "one size fits all" nature of regulation also lose some of their force once slippage is taken into account. If slippage were more or less uniform, then the ultimate level of compliance would also be uniform. Thus, the standard criticism-that the same level of control is being required of all sources within a category regardless of individual control costs or site-specific environmental impacts-might still hold true. It seems plausible, however, that both compliance costs and environmental impacts would be relevant in the negotiation process. A source with unusually high compliance costs has a greater incentive to resist government demands, while those costs may also have political ramifications such as lost jobs or a declining tax base that might limit the government's regulatory enthusiasm. On the other hand, high environmental impacts will create more pressure on the government for enforcement of the standards, and increase the likelihood of a citizen suit. Consequently, we might expect that enforcement (and thus the ultimate outcome) will be strictest for sources with low compliance costs and high environmental impacts, and weakest for sources with high costs and low impacts. As a result, the costs and benefits of pollution control will be roughly matched, rather than making the level of pollution control independent of individual circumstances.

A similar phenomenon might also shift the results of a cost-benefit analysis of the standards, even assuming eventual full compliance. It is at least plausible that the most rapid compliance will involve sources with lower compliance costs or high environmental impacts, while the greatest delays will occur for sources with high costs or low impacts. Consequently, the balance between costs and benefits may be most favorable in the early years of implementation. But in determining whether to adopt the regulation, costs and benefits must be discounted to present value."

77. See FARBER, ECo-Pragmatism, supra note 3, at 133-62. 
Consequently, the early years (which are less discounted) count more heavily than later years. Even if the sum total of all compliance costs is greater than the sum total of all environmental benefits, the cost-benefit analysis could still be favorable, if the benefits are disproportionately accrued early in implementation and the costs are disproportionately lagged. ${ }^{78}$ Whether, or how often, this conclusion holds is speculative, but it is at least clear that an assessment of existing regulations cannot ignore the dynamics of the implementation process.

Recognizing the importance of slippage may well put a new twist on some other familiar issues. One recent debate revolves around whether uniform national standards are justified in order to prevent a "race to the bottom" among states. ${ }^{79}$ But often, the supposed uniform standards are both incomplete and under-enforced, with much state variation the inevitable result. Thus, the supposedly uniform federal standards may exhibit considerable variation at the implementation level. So the practical issue is not whether to have complete national uniformity, which is a chimera, but whether the constraining effect of the national standards on local variation is useful. ${ }^{80} \mathrm{It}$ is quite possible that full implementation of uniform national standards would be undesirable, but that partial implementation is useful as a safeguard against local regulatory breakdowns.

Recognizing the amount of slippage in the implementation process might also have some effect on how we approach the procedures for issuing standards. If we expect standards to be completely implemented, it makes sense to insist on full deliberation and a high standard of rationality when the standards are crafted. But to the extent that the standards are mostly opening gambits in a prolonged bargaining process, this insistence seems somewhat misplaced. Moreover, the considerable uncertainty about how a standard will actually be implemented naturally makes any confident assessment of the regulation before issuance problematic.

The argument here is not that a recognition of slippage necessarily reverses the conclusions one would reach about regulatory standards and how they should be issued. Slippage is only part of the story, and in some settings it may be more important than in others. But in at least some settings, it might significantly undermine the standard economic critiques

78. Of course, the regulations might still be suboptimal in the sense that the costbenefit analysis could be made even more favorable by eliminating the later phase of compliance. But this may or may not be feasible, since the threat of strict standards may be needed for enforcement purposes.

79. See David L. Shapiro, Federalism: A Dialogue 42-43, 81-82 (1995); Richard L. Revesz, Rehabilitating Interstate Competition: Rethinking the 'Race-to-the-Bottom' Rationale for Federal Environmental Regulation, 67 N.Y.U. L. REv. 1210 (1992); Daniel A. Farber, Environmental Federalism in a Global Economy, 83 VA. L. REV. 1283 (1997).

80. The question then would be: is the federal process well designed to intervene in the circumstances where the interstate "market for regulation" is likely to misfire (e.g., when public choice problems distort local regulation)? 
of federal "command and control" regulation. ${ }^{81}$ The reason is simple: in those settings, command and control regulation does not really exist in the first place. Instead, what looks like a regulatory command is only one stage in a larger and more flexible process.

\section{Reinventing Reinvention}

In various guises, the idea of reinventing regulation is currently in vogue. The basic idea is to move from a command-and-control model toward one involving more negotiation and more room for innovation by sources and creativity by regulators. ${ }^{82}$ As we saw in the earlier discussion of creative compliance (or affirmative slippage), some intriguing efforts at implementing these ideas have already been made, particularly during the Clinton Administration.

The concept of slippage may make these proposals less threatening and unfamiliar, since bargaining is already such an important part of the regulatory regime. ${ }^{83}$ But understanding the current role of slippage in the system also provides two additional reasons to be careful about implementing these proposals.

First, if there is already slippage between supposedly clear regulatory standards and actual conduct, we must wonder how much additional slippage might occur between the reinvented regulatory regime and actual compliance. That is, will we have slippage (from the reinvented regulations to actual compliance) on top of slippage (from original standards to reinvented regulation)? Currently, the informal and partially illicit nature of creative compliance measures is a disincentive for sources to enter into those bargains with EPA that informally modify compliance requirements. But it is also a strong incentive to keep those bargains, once made, because a breach of the bargain can easily lead the regulator to revert to the formally binding regulatory standards. Thus, the source may have some reluctance to initiate a second round of negotiation over how fully to implement the bargain resulting from the first round. But when the bargain itself is given full formal recognition, it may become the starting point for yet another round of negotiation, leading to further

81. See Bruce A. Ackerman \& Richard B. Stewart, Comment, Reforming Environmental Law, 37 STAN. L. REv. 1333 (1985).

82. See, e.g., E. Donald Elliot, Toward Ecological Law and Policy, in Thinking Ecologically: The Next Generation of Environmental Policy 170 (Marian Chertow \& Daniel Esty eds., 1997); FARBER, Eco-PrAGMATISM, supra note 3, at 163-98; Jody Freeman, Collaborative Governance in the Administrative State, 45 UCLA L. REv. 1 (1997); Archon Fung et al., After Backyard Environmentalism: Towards New Model of Information-Based Environmental Regulation (1998) (unpublished manuscript, on file with author).

83. By the same token, since "reinvention" is to some extent already in place, we may have already gained a significant part of the potential benefit of reinvention-that is, as discussed in the previous subsection, the status quo may not be as rigid and inefficient as it is often portrayed. 
slippage. If we cannot count on full compliance with supposedly clearcut national standards, we might also be unwise to assume that deals with individual sources will be a firmer basis for further enforcement efforts. Indeed, monitoring and enforcement problems might be even greater with more flexible, result oriented requirements for sources than with simpler, technology-based standards.

Second, slippage raises substantial problems of transparency and accountability. In an effort to ensure the transparency and accountability of conventional regulation, society has adopted a variety of procedures, ranging from the constitutional requirements for legislation (bicameralism and presentment) to the Administrative Procedure Act's requirements for rulemaking and judicial review. Slippage erodes these guarantees. One goal of Part I was to show how far the regulatory process has often deviated from the public, formally binding standards supposedly required by law. Much important policy is made through regulatory inaction, settlement of litigation, and other techniques that operate outside of full public view. Moreover, these techniques do not contain the usual opportunities for public input or the normal mandates for deliberative decisionmaking. They take place, in other words, very much in the shadow of the law, not in the light of public deliberation. In one way or another, the same problems have plagued various reinvention efforts, which have been repeatedly criticized for their lack of procedural regularity and public accountability. ${ }^{84}$ These problems are not insurmountable, but efforts to provide more accountability and transparency are likely to hamper the collaborative process that is at the heart of reinvention. ${ }^{85}$

Reinvention is close to the idea of affirmative slippage discussed previously in this Article. The risk, however, is that frameworks designed to foster affirmative slippage will instead provide fertile ground for negative slippage-in other words, a reversion to the environmental evils that the regulatory system was designed to thwart in the first place.

For environmental scholars, this discussion suggests several potential directions for research. We need more evaluations of existing reinvention efforts, some of which are just now beginning to appear. We also need sustained analysis of how to manage the tradeoffs between unhampered regulatory collaboration and values such as transparency and accountability. We need more systematic efforts to think through the bargaining process itself. How should we design the rules to promote opti-

84. See Freeman, supra note 82 , at $77-87$. On the general issue of public participation in environmental decisions, see generally BRUCE A. WILliams \& AlBert R. Matheny, Democracy, Dialogue, and Environmental Disputes: The Contested LANGUAGES OF Social REgulation (1995).

85. The mixed experience with an earlier version of reinvention, negotiated rulemaking, may be illuminating. See Cary Coglianese, Assessing Consensus: The Promise and Performance of Negotiated Rulemaking, 46 DukE L.J. 1255 (1997); William Funk, Bargaining Toward the New Millenium: Regulatory Negotiation and the Subversion of the Public Interest, 46 Duke L.J. 1351 (1997). 
mal (and enforceable) bargains? ${ }^{86}$ In short, we need to work out the best mechanisms for managing slippage-_"best" in terms of both outcomes and process values.

\section{Putting the Brakes on Slippage}

As we have discussed, the existence of negative slippage may actually ameliorate some of the flaws in the current regulatory system, and affirmative slippage may provide the opportunity for innovative solutions to environmental problems (while also raising concerns of its own). But slippage is another name for noncompliance, and our first response to noncompliance-that something should be done to eliminate it-may sometimes be the right one. Therefore, scholars need to devote attention to more than just the issue of how to obtain compliance with environmental rules. No doubt the answers involve to some extent the application of ordinary common sense: for example, higher penalties will probably improve compliance, as will lower standards of proof for the enforcement agency. But there are some other ways to think about the problem that may be helpful.

The first is law and economics. The question is how to obtain an optimal level of compliance, given a costly and imperfect system of sanctions. Economists have devoted considerable attention to this general class of problems, and there is good reason to think that their findings might be illuminating. In particular, there is a useful body of work on corporate compliance that seems relevant to environmental law. ${ }^{87}$

The second is the growing body of work dealing with social norms and their relationship to legal compliance ${ }^{88}$ Exploring the causes of compliance has been a central issue in international law. Given the absence of effective enforcement mechanisms, why do nations nevertheless often comply? The answer, in one form or another, seems to be that nations find themselves pressured to adhere to accepted norms of conduct, for a variety of reasons relating to internal political pressure, fear of losing international standing, retaliation by other nations, and simple belief by decisionmakers in the legitimacy of the norms. ${ }^{89}$

86. For instance, game theoretic analysis of bargaining might have some helpful things to say about how to create incentives for information disclosure during the process. See infra text accompanying note 94.

87. See Steven McG. Bundy \& Einer Elhauge, Knowledge About Legal Sanctions, 92 MiCh. L. REv. 261 (1993); John C. Coffee, Jr., Does "Unlawful" Mean "Criminal"?: Reflections on the Disappearing Tort/Crime Distinction in American Law, 71 B.U. L. REv. 193 (1991); Cynthia Williams, Corporate Compliance with the Law in the Era of Efficiency, 76 N.C. L. REV. 1265 (1998) (critiquing this approach).

88. See Richard H. McAdams, The Origin, Development and Regulation of Norms, 96 Mrch. L. Rev. 338 (1997); Symposium, Social Norms, Social Meaning, and the Economic Analysis of Law, 27 J. LEG. STUD. 537 (1998).

89. See Abram Chayes \& Antonia Handler Chayes, The New Sovereignty: COMPLIANCE WITH INTERNATIONAL REgulatory AgREEMENTS (1995); George W. 
One can imagine similar incentives for corporations to obey environmental laws. Efforts to increase compliance might well focus on reinforcing these norms, for example by "shaming" corporations through public disclosure of noncompliance $e^{90}$ or by taking steps to increase the power of environmental managers within the corporate hierarchy. ${ }^{91}$ Stricter enforcement, as such, may not be the only approach or even the best one toward increasing compliance.

Through most of this Article, the underlying legal standards have been taken as a given, and the focus has been on the slippage between those standards and ultimate levels of environmental protection. But we also need to consider the extent to which changes in the underlying regulatory scheme could help induce greater compliance (eliminating negative slippage) or foster desirable bargains between regulators and sources (promoting positive slippage)..$^{92}$ One notable recent effort along these lines is provided by Tom Merrill's analysis of transboundary pollution issues..$^{93}$ Based on the economic literature about dispute settlement, he draws some tentative conclusions about how legal rules should be designed to foster constructive bargaining:

Synthesizing these academic contributions, it would seem that the legal system can best facilitate Coasean bargains in small numbers settings by adopting rules that: (1) make it relatively easy for the parties to predict the outcome if no agreement is reached; (2) offer minimal opportunities for either party credibly to take extreme or threatening positions toward the other party; and (3) force parties to disclose information about their true valuations of the possible outcomes to the dispute. Presumably, no legal rule will perfectly em-

Downs, Enforcement and the Evolution of Cooperation, 19 MrCH. J. INT'L L. 319 (1998); Harold Hongju Koh, Why Do Nations Obey International Law?, 106 YALE L.J. 2599 (1997) (book review).

90. Consider, for instance, the company that was required to post the following fullpage ads in major national newspapers:

\author{
WARNING
}

THE ILLEGAL DISPOSAL OF TOXIC WASTES WILL RESULT IN JAIL. WE SHOULD KNOW. WE GOT CAUGHT.

RODGERS, supra note 2 , at 663.

91. On the general question of how to increase voluntary corporate self-regulation, see John W. Maxwell et al., Self-Regulation and Social Welfare: The Political Economy of Corporate Environmentalism (1998) (unpublished manuscript, on file with author).

92. A full consideration of this problem would require a better understanding of agency negotiating behavior, in order to determine the extent to which the agency's incentives correspond to the public interest.

93. Merrill, supra note 26 , at $988-95$. 
body all three of these attributes; there will have to be some tradeoffs. The relative question is comparative $\ldots .^{94}$

This formulation is surely not definitive, but it does offer useful guidance about how to design regulatory standards. Most importantly, it directs our attention in the right direction: not toward the question of what standards, if fully implemented, would be ideal, but rather toward the question of what standards will, after the compliance and negotiation process, result in the best outcomes. The answers to the two questions might be quite different. A standard that specifies an optimal level of pollution control might lead to bargaining breakdowns because the regulated party lacks sufficient incentive to make a deal, or to the wrong level of pollution control after negotiations between the source and the regulatory agency.

\section{Slippage and Pedagogy}

So far, we have focused on how the concept of slippage might illuminate legal doctrine and environmental policy. But slippage is not just important for legal scholarship. It is also important in terms of how environmental law is taught. One lesson is that the introductory environmental courses need to pay more attention to permitting and enforcement issues, so students get a clear understanding of the relevant legal regimes. The casebooks are just beginning to add chapters dealing with these issues. The more difficult challenge is to teach students how to deal creatively with slippage-or in practical terms, how to negotiate desirable solutions in the shadow of the standards. The ideal approach is probably some kind of active learning, whether in the form of problems, simulations, or clinical work. At the very least, students should be exposed to some detailed case histories on the business school model, so they can get a sense of how the process really works.

\section{Curriculum}

It seems clear that implementation issues do not receive the attention they deserve in the basic environmental law class. To avoid invidious commentary about other authors, consider the Findley \& Farber casebook. ${ }^{95}$ The Fifth Edition does have a separate chapter on "Environmental Liability and Enforcement," but this chapter is only about 160 pages out

94. Id. at 994. Recent studies of international environmental negotiations may also shed light on the preconditions for successful bargains. See Mostafa Tolba, GLobaL ENVIRONMENTAL DiplomacX: Negotiating ENVIRONMENTAL AgREEMENTS FOR THE WORLD, 1973-1992 (1998).

95. FINDLEY \& FARBER, supra note 36 . This casebook actually devotes somewhat more attention to implementation than a number of its competitors. 
of an 838 page book, and half of the chapter is devoted to liability for hazardous waste releases. True, enforcement related issues do appear from time to time elsewhere in the book. ${ }^{96}$ But some significant topics like permitting get short shrift, and in general, implementation takes second-place to standard-setting in most of the discussion.

This treatment of implementation issues seems inadequate, but the solution is less than obvious. ${ }^{97}$ There is already too much material to cover in the basic course-too many statutes, too much administrative law, too many economic concepts. Expanding the discussion of compliance would leave even less space for other issues. Another possibility would be to weave implementation materials throughout the course, with the hope of providing a seamless presentation of both standard-setting and implementation in each area (but this is much easier said than done!). And of course, there is always the possibility of condensing other material; for example, by sharply contracting the coverage of NEPA (on the grounds of its being passe, perhaps).

Neither approach seems completely satisfactory. A better solution might be to split the basic course in two, with one course covering environmental standards and the other course covering implementation. The latter course could include civil and criminal enforcement, civil liability (both statutory and common law), and judicial review. Still, this solution is not without its costs, in terms of the time demands it makes of students and the resource demands on law schools (not to mention the unavailability of a textbook for the implementation course). Moreover, by postponing discussion of implementation to the second course, this curriculum might leave some students with a distorted view of the realities of environmental law. Still, among the available solutions, this may well be the best. It would also have the advantage of providing intensive coverage for the kinds of issues-permitting, enforcement, and liabilitywhich most students are likely to face as lawyers.

\section{Techniques}

An even knottier problem relates to teaching techniques. Some aspects of implementation (or its converse, slippage) lend themselves to traditional classroom teaching. There is a considerable amount of legal doctrine to be learned and manipulated; there is also likely to be an increasing amount of legal theory devoted to environmental compliance,

96. For instance, there is a subsection on nonattainment and noncompliance under the Clean Air Act, and a long note about civil penalties. See id. at 385-87.

97. One possibility would be to focus the course on a single statute such as the Clean Water Act, allowing close attention to policy, rulemaking, and implementation, but at the cost of leaving students completely ignorant of such matters as the existence of the Endangered Species Act or CERCLA. 
bargaining, and dispute resolution. Much of this material can probably be presented through lecture or class discussion.

But there are limits to how deeply students can understand these issues based only on doctrine and theory. Implementation is a classic arena for lawyering skills, and law schools are still struggling with how to teach those skills. Moreover, some of the most intriguing issues, involving affirmative slippage or the creative renegotiation of environmental requirements, are likely to arise in especially complex settings, making classroom presentation more difficult.

Although it is no easy task to design such programs, some form of active learning is called for here. The alternatives are familiar: in-house clinics, externships, simulations, and MBA-style case studies (particularly focusing on examples of positive slippage such as the negotiation of habitat conservation plans).$^{98}$ All of these alternatives have shortcomings, either in the kinds of material that can be presented, the degree of sophistication that they demand from students, or the resources they demand from law schools. But it should surely' not be news to environmental scholars that important problems tend to lack simple solutions.

The pedagogical problems presented by environmental slippage are real, but so are the pedagogical opportunities. To begin with, there is the advantage of being able to connect what we teach in environmental law to the kind of legal work that most of our students will actually do. Moreover, although environmental law has had links within the law school to administrative law and some other courses, ${ }^{99}$ focusing on slippage would allow us to forge connections with other colleagues and other parts of the curriculum, including criminal law (which is, in the end, all about enforcement), dispute resolution, remedies (another core enforcement issue), and lawyering skills.

\section{CoNCLUSION}

Slippage happens.

The most immediate questions are: How much? And, so what?

The argument in this Article has been that slippage is common, interesting, and important. Providing some statistical measure of overall environmental slippage seems impossible. Nevertheless, it is hard to imagine any environmental lawyer dismissing noncompliance as an un-

98. For discussions of some of the pedagogical possibilities, see Robert F. Kennedy, Jr. \& Steven P. Solow, Environmental Litigation as Clinical Education: A Case Study, 8 J. EnvtL. L. \& LiTIG. 319 (1993); Heidi Gorovitz Robertson, Methods for Teaching Environmental Law: Some Thoughts on Providing Access to the Environmental Law System, 23 Colum. J. ENVTL. L. 237 (1998).

99. Land-use planning, natural resources courses such as water and public lands, and law and economics come to mind. 
important problem or suggesting that the implementation of environmental statutes has generally followed a straightforward path. Indeed, many readers of this Article will probably regard the prevalence of slippage as entirely obvious.

It may be less obvious that slippage is interesting and important. But consideration of slippage may illuminate our understanding of environmental regulation by showing how environmental standards, which have been the subject of so much attention (not to mention criticism), fit into the larger scheme of things. Thus, a number of the usual criticisms of command-and-control regulation may lose some of their sting, once we appreciate how much readjustment takes place between the issuance of standards and the actual behavior of the regulated parties.

The hardest question of all, however, is whether slippage is good or bad. Given its often unrealistic demands, it is hard to see how the system could operate without at least some degree of slippage-recall that Congress mandated an end to all water pollution by 1985 , a quixotic demand that is still part of the statute today. ${ }^{100}$ Without some escape hatch, industry might be overwhelmed by unrealistic regulatory burdens. Besides ameliorating the sometimes impractical demands found in the statutes, slippage has also provided an opportunity for some important innovations in environmental regulation.

But slippage also has an inevitable cost in terms of damage to our concept of the rule of law. Widespread noncompliance with formally binding requirements undermines the concept that good citizens-and even more so, governmental officials-obey the law. For this reason, as much as it engages our interest, and as much as it may be in some respects socially beneficial, slippage must also remain a troubling concept.

100. 33 U.S.C. § 1251(a)(1) (1994). 
HeinOnline -- 23 Harv. Envtl. L. Rev. 3261999 